\title{
Production Indicators and Levels of Corticosterone in Pullets Treated with Beak-Trimming Protocols
}

-Author(s)
Vieira Filho JA'
Garcia EA'
Oba E"I
Santos TA'
Molino AB"II
Silva APIV
Pelícia K
Paz ICLA'
I Department of Animal Production, Faculty
of Veterinary Medicine and Animal Science,
University of Sao Paulo State, Botucatu, Sao
Paulo, Brazil;
" Department of Animal Reproduction,
Faculty of Veterinary Medicine and Animal
Science, University of Sao Paulo State,
Botucatu, Sao Paulo, Brazil;
III Department of Animal Production
and Nutrition, University of Sao Paulo,
Pirassununga, Sao Paulo;
Iv Technical Supervisor of LOHMANN
BRAZIL®;
Department of Animal Science, State
University of Mato Grosso, Pontes Lacerda,
Mato Grosso, Brazil.

\section{-Mail Address}

Corresponding author e-mail address Javer Alves Vieira Filho

Br $354 \mathrm{Km}$ 494, caixa postal 115, CEP 35570-00, Formiga - MG

Email: javeralves@yahoo.com.br

\begin{abstract}
The aim of this study was to compare the effects of beak trimming by hot blade or infrared radiation on production indicators and plasma levels of corticosterone in pullets. During the rearing phase, an entirely random delineation was used a $2 \times 3$ factorial design (two different techniques for beak trimming $\times 3$ strains), a total of six treatments with six repetitions of 20 hens. In the growing phase, the previous treatments were divided into 12, with eight repetitions with seven hens. These treatments were then distributed in a factorial design of $2 \times 3 \times 2$ (two methodologies for beak trimming during rearing phase $x$ three strains $x$ with or without beak trimming at ten weeks of age). In the rearing phase the birds treated by infrared radiation had a lower total consumption and a longer beak length. In the growing phase, the execution of beak trimming at ten weeks of age, led to a lower total consumption and a lower body weight, but a better food conversion, when compared to those hens that did not have beak treatment. Beak trimming at ten weeks did not change the plasmatic levels of corticosterone.
\end{abstract}

\section{INTRODUCTION}

The poultry production has undergone significant transformations in the wake of a change of thought by the consumer market. This consumer seeks more information with the way production animals are being bred, with special attention to aspects concerning their welfare. In the case of laying hens, the housing in cages and the beak trimming are the points that have generated most discussion in relation to welfare.

The beak trimming has the objective of avoiding cannibalism and also ensuring the uniform consumption of the diet (Craig \& Lee, 1990; Appleby, 1998; Carruthers et al. 2012; Sun et al. 2012). This methodology is common in layer flocks, its application is traditionally between seven and ten days of age, and after, repeated between six and twelve weeks. This period is very important for the commercial flocks, because there is the development of internal organs, bones and the reproductive system, which together environmental factors will determine the productive longevity of birds (Rombola et al. 2008).

This technique is aggressive to the beak tissue, by cutting and cauterizing, the practice of beak trimming is constantly criticized by non-governmental organizations and consumers. In this way, there is justification of greater efforts in working towards a review and enhancement of methodologies which contribute to the quality of the final product and also improvement in breeding and raising conditions.

Under this perspective, the infrared beak trimming is a method that arises as an alternative to conventional beak trimming. This method makes it possible for the beak to be treated on the first day, when the chick is still being hatched, by the exposure of the beak to infrared 
Vieira Filho JA, Garcia EA, Oba E, Santos TA, Molino AB, Silva AP, Pelícia K, Paz ICLA
Production Indicators and Levels of Corticosterone in Pullets Treated with Beak-Trimming Protocols radiation. This method showed some advantages, such as the possibility of counting and vaccinating the birds, and in some cases, to get a greater uniformity of the area treated, because it is an automated process. Apart from the benefits mentioned above, treatment with infrared radiation is an option which brings less harm to the tissue of the beak, and hence less change to the nutritional behaviour of the birds (Dennis \& Cheng, 2010). It is a method which does not leave any exposed wounds and hence brings a significant reduction in the possibility of infections and inflammation during the days immediately following the treatment (MarchantForde \& Cheng, 2010).

The inflammatory process and the stress that is generated after the beak trimming starts physiological changes, among which there is the increase in the secretion of corticosterone, this hormone secreted under stress and also in cases of occurrence of pain and inflammation (Cheng \& Muir, 2007). It is also involved in the process of maintenance of organic homoeostasis, bringing behaviour changes and alterations to the metabolism of carbohydrates, proteins and lipids (Bamberger et al. 1996; Davis et al. 2004).

The aim of this study was to compare the effects of beak trimming by hot blade or infrared radiation on production indicators and plasma levels of corticosterone in pullets.

\section{MATERIAL AND METHODS}

This experiment was carried out in the Sao Paulo State University, Faculty of Veterinary Medicine and Animal Science, and conducted during the rearing and growing phases ( $1^{\text {st }}$ day of life through to the age of 17 weeks). The birds were placed first in rearing aviary (from the $1^{\text {st }}$ through the $6^{\text {th }}$ week) and then in growing aviary (from the $7^{\text {th }}$ through the $17^{\text {th }}$ week).

All methodologies used in this research were approved by the Ethics Commission for the Use of Animals (CEUA), protocol 11/2013-CEUA, of the School of Veterinary Medicine and Animal Science (FMVZ) in Botucatu.

\section{Birds and experimental treatments}

For the rearing phase, we used 720 one-day chicks, housed in metallic cages, with $50 \times 80 \times 35 \mathrm{~cm}$, with a density of $100 \mathrm{~cm}^{2} /$ bird. Each cage was equipped with a food tray, a nipple-type drinker, and also an electric heating device. During this phase, there was an entirely random delineation using a factorial design of $2 \times 3$ (beak trimming with infrared radiation or using hot blade $x$ strains Lohmann ${ }^{\circledR}$ LSL, Hy-Line ${ }^{\circledR}$ W-36 and Lohmann ${ }^{\circledR}$ Brown), and a total of six treatments with six repetitions, and 20 birds per experimental unit.

The treatment with infrared radiation was done in the first day of life, in the hatchery, with equipment developed by the company Nova-Tech Engineering, following the specifications: beak treatment at $2 \mathrm{~mm}$ from the nostril, intensity of light of $52 \mathrm{~nm}$, and a mirror as reflection material. The conventional method of beak trimming using hot blade followed these guidelines: cut and cauterisation at $4 \mathrm{~mm}$ from the nostril after seven days of life, and the blade kept at a temperature of around $700^{\circ} \mathrm{C}$.

As from the $6^{\text {th }}$ week of life, 672 birds were transferred to a growing aviary, being kept in metallic cages $(100 \times 50 \times 50 \mathrm{~cm})$, with stocking density of 357 $\mathrm{cm}^{2} /$ bird. Each cage had individual food trays and nipple-type for drinking. During the growing phase, an entirely random delineation with a factorial design $2 \times 3 \times 2$, was used ( 2 methodologies of beak trimming in rearing phase $\times 3$ strains $\times$ with or without beak trimming). In the growing phase the beak trimming was carried out at ten weeks of life, with the beak treatment at $7 \mathrm{~mm}$ from the nostril and the blade kept at a temperature of around $700^{\circ} \mathrm{C}$. Thus, the six treatments used in the rearing phase were divided into 12 treatments with eight repetitions on seven birds, for each experimental unit.

The nutritional requirements, as also the light programmes used for the two phases followed what is recommended by the manuals of the strains. Food and water have been supplied ad libitum.

\section{Production indicators}

During the experimental period, the following indicators were assessed: initial weight, all birds being weighed in their housing; total consumption of feed, as obtained at the end of the rearing and growing phases, through the total of the feed consumed during the weeks of the experiment, shown in grams/ bird; final weight at rearing and growing, obtained by the individual weighing of all the birds in 3 repetitions per treatment; feed conversion, obtained through the ratio between consumption of feed and the average weight of the birds, shown in grams of feed/grams of weight (creates) and $\mathrm{kg}$ of feed/kg of weight (growing); uniformity, obtained through weekly individual weighing of all the birds in 3 repetitions per treatment; cannibalism and mortality, obtained through daily records and shown as a percentage; and length of the beak, measured with digital pachymeter (precision of $0.01 \mathrm{~mm}$ ) at the end of the rearing and growing. 


\section{Dosage of corticosterone}

Samples were collected from $1 \mathrm{~mL}$ of blood of a bird by plot, by puncturing the ulnar vein in heparinized syringes at 7,14 and 21 days after the application of beak trimming at ten weeks of age. After collection, the blood was kept in heparinized syringes, and these in a refrigerated cooler. Plasma was obtained by centrifugation at $3500 \mathrm{~g}$ for $30 \mathrm{~min}$ and frozen at $20^{\circ} \mathrm{C}$.

For the analyzes of the plasma, samples were diluted in diluent steroid in the ratio of 1:100 and after this, an analysis by radioimmunoassay according to Etches (1976) using a commercial kit ImmuChenTM Double Antibody Corticosterone 125 | RIA, MP Biomedicals, was done following the manufacturer's guidelines.

\section{Statistical analysis}

The data was subjected to analysis of variance using the SAS 9.2 programme (SAS Institute Inc, 2008) with the means being compared using the Tukey test at $5 \%$. The variables that did not show a normal distribution were transformed using decimal log correction, for later analysis.

\section{RESULTS AND DISCUSSION}

During the rearing phase, there was no mortality or cannibalism in any of the experimental treatments, and there has been no interaction between the factors that have been studied. The results of the performance indicators are shown in Table 1.

Table 1 - Production performance indicators at the end of the rearing phase (6 weeks)

\begin{tabular}{|c|c|c|c|c|c|c|c|c|}
\hline & & SW & (g) & $C(\mathrm{~g} / \mathrm{bird})$ & FW & FC $(g / g)$ & UN $\quad(\%)$ & $\mathrm{BL}(\mathrm{mm})$ \\
\hline \multirow{3}{*}{ Strains } & Lohmann LSL & \multicolumn{2}{|c|}{$39.21 \mathrm{~A}$} & $989.02 \mathrm{~A}$ & $422.16 \mathrm{~B}$ & $2.34 \mathrm{~A}$ & $75.27 \mathrm{~B}$ & 7.71 \\
\hline & Hy-Line ${ }^{\circledR}$ W-36 & \multicolumn{2}{|c|}{$38.83 \mathrm{~B}$} & $961.84 \mathrm{C}$ & $400.53 C$ & $2.40 \mathrm{~A}$ & $88.19 \mathrm{~A}$ & 7.71 \\
\hline & Lohmann Brown & \multicolumn{2}{|c|}{$34.34 \mathrm{C}$} & $973.20 \mathrm{~B}$ & $444.06 \mathrm{~A}$ & $2.19 \mathrm{~B}$ & $83.33 \mathrm{~A}$ & 7.34 \\
\hline \multirow{2}{*}{ Beak trimming } & Infrared & \multicolumn{2}{|c|}{37.39} & $969.67 \mathrm{~B}$ & 421.57 & 2.30 & 84.62 & $7.82 \mathrm{~A}$ \\
\hline & Hot blade & \multicolumn{2}{|c|}{37.53} & $979.70 \mathrm{~A}$ & 422.92 & 2.19 & 79.90 & $7.35 \mathrm{~B}$ \\
\hline \multicolumn{2}{|l|}{$\mathrm{CV}(\%)$} & \multicolumn{2}{|c|}{6.39} & 3.56 & 5.19 & 5.41 & 8.63 & 7.33 \\
\hline \multicolumn{2}{|l|}{ Strains } & \multicolumn{2}{|c|}{$<0.05$} & $<0.05$ & $<0.05$ & $<0.05$ & $<0.05$ & 0.11 \\
\hline \multicolumn{2}{|l|}{ Beak trimming } & \multicolumn{2}{|c|}{0.63} & $<0.05$ & 0.76 & 0.20 & 0.28 & $<0.05$ \\
\hline \multicolumn{2}{|c|}{ Strains $\times$ Beak trimming } & \multicolumn{2}{|c|}{0.55} & 0.29 & 0.60 & 0.72 & 0.54 & 0.15 \\
\hline
\end{tabular}

A, B, C means followed by different letters in the column differ statistically based on the findings of the Tukey test. SW: starting weight (g); C: feed consumption (g/bird); FW: final weight (g); FC: feed conversion (g feed/g body weight); UN: uniformity (\%); BL: beak length (mm)

For beak length, there was no observed difference between strains. However, we did find an effect of this factor upon other variables such as starting weight, total consumption of bird feed, weight at the end of the rearing phase, food conversion and uniformity. In relation to the initial weight, the results show that the Lohmann ${ }^{\circledR}$ Brown strain had a lower body weight in the housing when compared to other strains. This result could be caused by the differences between the ages of the breeder, with those of the Lohmann ${ }^{\circledR}$ Brown being younger than the others. An experiment with breeders of the Dekalb strain aged between 32 and 57 weeks show that both the weight of the egg and the weight of the chick have increased, in proportion to the increased ages (Tanure et al. 2009).

When analysing the total consumption, we see that the birds of the Lohmann ${ }^{\circledR}$ LSL strain have higher consumption when compared to those of the Lohmann ${ }^{\circledR}$ Brown and Hy-Line ${ }^{\circledR}$ W36 strain. For final body weight, it was observed that the birds of the Lohmann ${ }^{\circledR}$ Brown, even though they are less heavy at birth, also show greater weight gain, reaching the end of the breeding period heavier than the birds of the light strains. This result is expected, as semi-heavy strains are genetically different and with greater body when compared to birds from lighter strains. In an experiment comparing light and semi-heavy strains, researchers have proved that the main difference between them is regarding the quantity of feed ingested and also body weight, these being characteristics that are defined based on the difference between the genetic standards of each of the strains that have been tested (Rombola et al. 2008).

We could also see a difference for feed conversion ( $\mathrm{g}$ of feed/g of body weight), where the birds of the Lohmann ${ }^{\circledR}$ Brown had better values when compared to the other strains, which can be justified by the greater genetic potential for the growth of these birds. There was also a difference between the lineages in terms of uniformity of weight, with the birds of the Lohmann Brown ${ }^{\circledR}$ and Hy-Line ${ }^{\circledR}$ W-36 showing better uniformity of weight when compared to the Lohmann ${ }^{\circledR}$ LSL.

We have not found any differences in the beak trimming factor influencing performance indicators as 
assessed, except for total consumption and beak length. The birds treated using the hot blade methodology have shown a higher average consumption of food but smaller beaks, at the end of the rearing period, when compared to the birds that have had their beaks treated using infrared radiation.

The results for beak length confirm those obtained by Dennis et al. (2009), who compared the treatment of beaks by hot blades and infrared radiation, noting that the birds treated using the alternative methodology show longer beaks and a lower occurrence of calluses or other deformities. In relation to accumulated consumption, the results here obtained disagree with those shown by Glatz (2003), and the author highlights that beak size does indeed have an effect on feed consumption, with birds with longer beaks consuming more feed when compared to those with smaller beaks.

During the growing phase, there was no case of mortality or cannibalism in any of the experimental treatments, and there has been no visible interaction between the factors that have been studied, except for beak length, which showed an interaction between strains and beak trimming in the growing phase. The results of the performance indicators are shown in Table 2.

Table 2 - Production performance indicators at the end of the growing phase (17 weeks)

\begin{tabular}{|c|c|c|c|c|c|c|c|}
\hline & & C $\quad(\mathrm{kg} / \mathrm{bird})$ & $\begin{array}{l}\text { FW } \\
(\mathrm{kg})\end{array}$ & $\mathrm{FC}(\mathrm{kg} / \mathrm{kg})$ & Un (\%) & $B \mathrm{~L}$ & $(\mathrm{~mm})$ \\
\hline \multirow{3}{*}{ Strains } & Lohmann LSL & $5.20 \mathrm{~B}$ & $1.215 \mathrm{~B}$ & $4.29 \mathrm{~A}$ & 88.75 & $10.60 \mathrm{~A}$ & \\
\hline & Hy-Line ${ }^{\circledR}$ W-36 & $4.98 \mathrm{C}$ & $1.189 \mathrm{C}$ & $4.21 \mathrm{~A}$ & 88.12 & $10.38 \mathrm{~B}$ & \\
\hline & Lohmann brown & $5.38 \mathrm{~A}$ & $1.429 \mathrm{~A}$ & $3.75 \mathrm{~B}$ & 88.82 & $10.79 \mathrm{~A}$ & \\
\hline \multirow{2}{*}{$\begin{array}{l}\text { Beak trimming (first } \\
\text { week) }\end{array}$} & Infrared & 5.17 & $1.287 \mathrm{~A}$ & 4.08 & 90.00 & 10.61 & \\
\hline & Hot blade & 5.20 & $1.267 \mathrm{~B}$ & 4.08 & 86.77 & 10.57 & \\
\hline \multirow{2}{*}{$\begin{array}{l}\text { Beak trimming (10 } \\
\text { weeks) }\end{array}$} & With & $5.00 \mathrm{~B}$ & $1.259 \mathrm{~B}$ & $3.98 \mathrm{~B}$ & 89.79 & $9.40 \mathrm{~B}$ & \\
\hline & Without & $5.38 \mathrm{~A}$ & $1.296 \mathrm{~A}$ & $4.19 \mathrm{~A}$ & 86.97 & $11.78 \mathrm{~A}$ & \\
\hline \multicolumn{2}{|l|}{$\mathrm{CV}(\%)$} & 5.19 & 9.07 & 7.23 & 6.38 & 10.53 & \\
\hline \multicolumn{2}{|l|}{ Strains (S) } & $<0.05$ & $<0.05$ & $<0.05$ & 0.97 & $<0.05$ & \\
\hline \multicolumn{2}{|c|}{ Beak Treatment- creates (C) } & 0.07 & $<0.05$ & 0.18 & 0.32 & 0.74 & \\
\hline \multicolumn{2}{|c|}{ Beak Treatment - growing (G) } & $<0.05$ & $<0.05$ & $<0.05$ & 0.40 & $<0.05$ & \\
\hline \multicolumn{2}{|c|}{$\mathrm{S} \times \mathrm{C}$} & 0.46 & 0.91 & 0.26 & 0.22 & 0.86 & \\
\hline \multicolumn{2}{|l|}{$S \times G$} & 0.18 & 0.32 & 0.41 & 0.84 & $<0.05$ & \\
\hline \multicolumn{2}{|l|}{$C \times G$} & 0.94 & 0.22 & 0.40 & 0.25 & 0.07 & \\
\hline \multicolumn{2}{|l|}{$\mathrm{S} \times \mathrm{C} \times \mathrm{G}$} & 0.96 & 0.48 & 0.08 & 0.49 & 0.75 & \\
\hline
\end{tabular}

A, B, C means followed by different letters in the column differ statistically based on the findings of the Tukey test. C: feed consumption (kg/bird); FW: final weight (kg); FC: feed conversion (kg feed/kg body weight); UN: uniformity (\%); BL: beak length (mm)

There has been no difference for uniformity, between the different strains tested. Within the strains factor, we have observed a difference related to the variables: total consumption of feed, weight at the end of the growing phase and feed conversion. It was the semi-heavy strain that had the highest consumption of animal feed and also the highest body weight at the end of the growing phase and thus better food conversion, when compared to the others.

The result obtained for the total consumption of animal feed goes against what was found in the studies by Oliveira et al. (2002), the authors showed that the lighter laying hens had a higher consumption of chicken feed when compared to the semi-heavy laying hens. This difference could be due to the fact that the authors mentioned having used semi-heavy laying hens, different from the one used in the present experiment.

Regarding the beak trimming factor in the rearing phase, we only saw a difference for body weight at the end of the growing phase, meaning that birds that had their beaks treated using the methodology of infrared radiation were heavier when compared to those that were treated using conventional methodologies.

Similar results were found by Dennis \& Cheng (2010) who, comparing the methodology of beak treatment using infrared radiation to that of using hot blade, also observed a higher body weight for the birds treated using the methodology of infrared radiation. The authors suggest that the alternative treatment increases the sensory perception as result of less damage being caused to the mechanoreceptors of the beak, which brought a more uniform consumption of the diet and, as a result, higher body weight.

In the case of beak trimming in the growing phase, the results have shown differences for all the variables analysed, except uniformity of weight. The birds that did not have beak trimming after ten weeks consumed more food, having a higher body weight 
and a higher beak length; however, feed conversion was worse. In relation to feed conversion, the three strains shown did actually present an improvement in this characteristic, by means of the application of beak trimming after ten weeks, regardless of the methodology of beak treatment that had been used in the rearing phase.

These results suggest that the greater feed consumption could be a result of the larger beak, an aspect that facilitated the handling of the diet by the bird and, as a result, increased waste. Another aspect that has contributed to this difference was the recovery period after the execution of the beak trimming, as birds that have had their beaks trimmed need a longer period to return to their normal patterns of feed consumption, which has a bearing on the reduction of total consumption at the end of the growing phase and lower body weight.

Here we can see that, for the three strains studied, the application of beak trimming after ten weeks established a reduction of feed consumption and increased beak length, regardless of the methodology of beak treatment that had been used in the create phase. In the case of the Hy-Line ${ }^{\circledR} \mathrm{W}$-36 strain, this difference in consumption did not bring a reduction in weight at the end of the growing phase, but with the other two strains this reduction in the consumption of chicken feed brought about a decline in weight at the end of the growing phase.

These results match those shown by the studies of Lee \& Graig (1990) where the authors noted that birds that had their beaks trimmed at 12 weeks showed a reduction in the feed consumption with better feed conversion, but disagree with the findings of Araújo et al. (2005), who found no differences regarding feed conversion despite the lower feed consumption, as obtained for those birds who had their second beak treatment, mild or severe, at 12 weeks of age. In addition, Glatz (2003) showed that beak trimming has a direct effect upon the feed consumption by birds that had their beaks trimmed at 14 weeks. This author noted that birds that had been severely beak treated consumed $7.8 \mathrm{~g}$ feed/day less when compared to birds that had had moderate beak trimming. The author also notes that the birds that had undergone beak trimming in a severe way went less times to the drinking devices or food trays.

In the growing period, we saw an interaction between strains and beak trimming in the growing period, for the characteristic of beak length. The results have been presented in Table 3.
Table 3 - Interaction between strains and beak trimming at the growing phase, for beak length

\begin{tabular}{lccr}
\hline \multicolumn{3}{c}{ Beak Length (16 weeks) } \\
\hline Strains & With beak trimming & Without beak trimming & Mean \\
\cline { 2 - 3 } Lohmann LSL $_{\text {Hy-Line }}^{\circledR}$ W-36 & $9.28 \mathrm{Bb}$ & $11.93 \mathrm{ABa}$ & 10.60 \\
\cline { 2 - 3 } & $9.40 \mathrm{ABb}$ & $11.37 \mathrm{Ba}$ & 10.83 \\
Lohmann Brown & $9.54 \mathrm{Ab}$ & $12.05 \mathrm{Aa}$ & 10.79 \\
\cline { 2 - 3 } Mean & 9.40 & 11.78 & \\
\hline
\end{tabular}

A, B: means followed by different capital letters in the same column show statistical differences based on the Tukey test; $a, b$ : means followed by different small letters in the same line show statistical differences using the Tukey test.

It is possible to see that the beak trimming performed at the age of ten weeks, acts in a different way upon beak growth in the case of the three strains tested. Thus, we can say that beak trimming as it was performed is more effective in inhibiting beak growth in the case of the Lohmann ${ }^{\circledR}$ LSL than with the other two strains that have been tested. This result is confirmed by the shorter beak length shown by the birds of this strain.

On analysing the beak length in cases without the application of beak trimming at ten weeks, one can see that, out of the three strains tested, the birds of the HyLine ${ }^{\circledR} \mathrm{W}$-36 were those that showed the shortest beak length, probably due to the fact that they have smaller bodies when compared to the other two strains.

These results match those of studies where it is made clear that the length and also the shape of the beak are highly influenced by the type and degree of beak trimming that have been adopted (Jongman et al. 2008; Dennis \& Cheng 2012; Carruthers et al. 2012).

We have not seen any effect of the factors as here studied on the plasma levels of corticosterone during the growing phase, the values were in the range of 28.98 to $44.31 \mathrm{ng} / \mathrm{ml}$. It can be said that the beak trimming carried out $7 \mathrm{~mm}$ from the nostril at ten weeks of age was quite mild and generated little damage to the tissue, not being enough to interfere with plasma levels of corticosterone, as these were quite similar to the levels seen in birds that did not have their beaks trimmed. For the growing phase, one can infer that the application of beak trimming in the manner practiced by this study is quite feasible and has a low impact on the general welfare of the birds, as well as quicker recovery, ensuring that the animal soon returns to normal feed consumption and body development.

The increase in the plasma levels of corticosterone has a negative effect on consumption of food and in secretion of peptides involved with feeding (Liu et al. 2012). The practice of beak trimming is a source of pain and stress, especially when done severely, and 
Tabela 4 - Plasma levels of corticosterone, 7, 14 and 21 days after beak trimming at 10 weeks of age

\begin{tabular}{|c|c|c|c|c|}
\hline \multicolumn{5}{|c|}{ Plasma Corticosterone (ng/mL) } \\
\hline & & 7 days & 14 days & 21 days \\
\hline \multirow{3}{*}{ Strains } & Lohmann LSL & 35,54 & 44,31 & 31,01 \\
\hline & Hy-line W-36 & 36,79 & 33,74 & 31,53 \\
\hline & Lohmann brown & 33,62 & 31,78 & 28,39 \\
\hline \multirow{2}{*}{ Beak trimming (first week) } & Infrared & 33,49 & 30,85 & 31,70 \\
\hline & Hot blade & 37,13 & 42,37 & 28,92 \\
\hline \multirow{2}{*}{ Beak trimming (10 weeks) } & With & 34,08 & 38,39 & 31,64 \\
\hline & Without & 36,54 & 34,83 & 28,98 \\
\hline CV (\%) & & 11,01 & 11,26 & 9,38 \\
\hline Strains (S) & & 0,8172 & 0,1051 & 0,3824 \\
\hline Debicagem cria (D) & & 0,3793 & 0,3793 & 0,1618 \\
\hline Debicagem recria $(R)$ & & 0,5517 & 0,4875 & 0,1798 \\
\hline$S \times D$ & & 0,9854 & 0,1464 & 0,9854 \\
\hline$S \times R$ & & 0,4166 & 0,1047 & 0,0638 \\
\hline$D \times R$ & & 0,3314 & 0,0629 & 0,6215 \\
\hline$S \times D \times R$ & & 0,0605 & 0,0707 & 0,6115 \\
\hline
\end{tabular}

A, B: means followed by different capital letters in the same column show statistical differences based on the Tukey test; a,b: means followed by different small letters in the same line show statistical differences using the Tukey test.

this has an influence on feed consumption in the days immediately following the beak trimming, especially through the increased sensitivity resulting from the wound that is made by the process (Dennis \& Cheng, 2010; Gentle, 2011).

The study shows that one can reduce the negative impact that beak trimming has on physiology on the days immediately following beak treatment for commercial laying hens. The strains tested show to be adapted to protocols of beak trimming which are less invasive, meaning that the current study is an important tool for the updating of the programmes of beak trimming that are currently practiced in commercial poultry farms.

\section{CONCLUSION}

The treatment of beaks using infrared radiation may be successfully applied to the strains studied, thereby ensuring similar development in the initial stages. It was also possible to confirm the raising of hens with only one beak trimming by hot blade or infrared radiation, in the first week of age. The application of the beak trimming at ten weeks of age does not interfere with the plasma levels of corticosterone after the beak trimming.

\section{ACKNOWLEDGEMENTS}

The authors would like to thank the Research Support Fund of the State of Sao Paulo (FAPESP) for the financial support for the execution of this study.

\section{REFERENCES}

Appleby M. Modification of laying hen cages to improve behavior. Poultry Science 1998;(77):18 28-183 2.

Araújo LF, Café MB, Leandro NSM, Junqueira OM, Araújo CSS, Cunha MIR, et al. Desempenho de poedeiras comerciais submetidas ou não a diferentes métodos de debicagem. Ciência Rural 2005;35(1):169-173.

Bamberger CM, Schulte HM, Chrousos GP. Molecular determinants of glucocorticoid receptor function and tissue sensitivity to glucocorticoids. Endocrine Reviews 1996;(17):245- 261.

Carruthers C, Gabrush T, Schwean-Lardner K, Knezacek TD, Classen HL, Bennett $C$. On-farm survey of beak characteristics in White Leghorns as a result of hot blade trimming or infrared beak treatment. Applied Poultry Research 2012;(21):645-650.

Cheng HW, Muir WM. Mechanisms of agression and production in chickens:genetic variations in the functions of serotonina, catecholamine, and corticosterone. World's Poultry Science Journal 2007;(63):233- 254

Craig JV, Lee HY. Beak trimming and genetic stock effects on behavior and mortality frm cannibalism in white leghorn-type pullets. Applied Animal Behavior Science 1990;(25):107-123.

Davis GS, Anderson KE, Jones DR.The effects of different beak trimming techniques on plasma corticosterone and performance criteria in single comb white leghorn hens. Poultry Science 2004;(83):1624-1628.

Dennis RL, Fahey AG, Cheng HW. Infrared beak treatment method compared with conventional hot-blade trimming in laying hens. Poultry Science 2009;(88):38-43

Dennis RL, Cheng HW. A comparison of infrared and hot blade beak trimming in laying hens. International Journal of Poultry Science 2010;9(8):716-719.

Dennis RL, Cheng HW. Effects of different infrared beak treatment protocols on chicken welfare and physiology. Poultry Science 2012;(91):14991505 .

Etches RJ. A radioimmunoassay for corticosterone and its application to the measurement of stress in poultry. Steroids1976;(28):763-773. 
Vieira Filho JA, Garcia EA, Oba E, Santos TA, Molino AB, Silva AP, Pelícia K, Paz ICLA

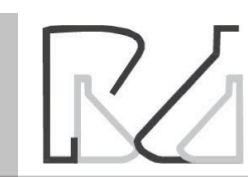

Production Indicators and Levels of Corticosterone in Pullets Treated with Beak-Trimming Protocols

Oliveira JR, Bertechini AG, Fassani EJ, Albino LFT, Freitas RTF, Fialho ET. Níveis de cálcio em dietas para poedeiras leves e semipesadas no segundo ciclo de produção. Ciência e Agrotecnologia 2002;26(5):1060-1067.

Rombola LG, Faria DE, Deponti BJ, Silva FHA, Faria Filho DE, Junqueira OM. Fontes de metionina em rações formuladas com base em aminoácidos totais ou digestíveis para frangas de reposição leves e semipesadas. Revista Brasileira de Zootecnia 2008;37(11):1990-1995.

SAS - Statistical Analysis System. SAS/STAT ${ }^{\circledR}$ 9.2. User's guide. Cary: SAS Institute Inc; 2008.

Sun G, Li Y, Kang X, Tian Y, Zhang H, Li K. Effect of beak trimming stress on the apoptosis and its related protein expression on chicken spleen. Journal of Integrative Agriculture 2012;11(4):639-645.

Tanure CBGS, Café MB, Leandro NSM, Baião NC, Stringhini JH, Gomes NA. Efeitos da idade da matriz leve e do período de armazenamento de ovos incubáveis no rendimento de incubação. Arquivo Brasileiro de Medicina Veteterinária e Zootecnia 2009:61(6):1391-1396. 
